\title{
Workshop on youth across Asia
}

John Townsend

Population Council

Ann P. McCauley

Kokila Agarwal

Follow this and additional works at: https://knowledgecommons.popcouncil.org/departments_sbsr-rh

Part of the Demography, Population, and Ecology Commons, Gender and Sexuality Commons, and the International Public Health Commons

How does access to this work benefit you? Let us know!

\section{Recommended Citation}

Townsend, John, Ann P. McCauley, and Kokila Agarwal. 1998. "Workshop on youth across Asia," Asia and Near East OR/TA Project Final Report. New Delhi: Population Council, FOCUS on Young Adults Program, and Futures Group International.

This Report is brought to you for free and open access by the Population Council. 


\title{
FINAL REPORT
}

\section{WORKSHOP ON YOUTH \\ ACROSS ASIA}

Kathmandu, Nepal

23-25 September 1997

John W. Townsend

Ann P. McCauley

Kokila Agarwal

In-house project \# 038.5

\author{
ORGANIZERS \\ Population Council \\ FOCUS on Young Adults Program \\ The Futures Group International
}

\author{
SPONSORS \\ United States Agency for International Development \\ Asia and Near East Bureau \\ Center for Population, Health and Nutrition
}

May 1998 


\section{TABLE OF CONTENTS}

Acknowledgments

Summary

iv

Introduction

1

Objectives

Participants and Their Expectations

Presentations

Supporting Materials

Sector lssues

4

Policy Environment

5

$\begin{array}{ll}\text { Field Visits } & 7\end{array}$

Country Plans

7

Conclusions

10

Six Month Follow-up

Appendixes

Agenda

A- 1

Participant List

A- 5 


\section{ACKNOWLEDGMENT}

The authors would like to acknowledge the generous support of the three partner organizations, the Population Council, the FOCUS on Young Adults Program, and the Futures Group International, which cooperated without reserve in the development of the workshop and its follow-up. This effort was made possible through the generous support of USAID. both the Global Bureau, Office of Health, Population and Nutrition, and the Regional Bureau for Asia and the Near East.

Special notice should be given to Jayanti Tuladhar for coordinating relations with Nepal, the host country for the workshop, Anil Paul and Monica Bhalla for support in workshop administration, Marion Carter for contributions in the development of the chart book, Anjali Nayyar and Sanjeev Kumar for communication networking, Sagri Singh for review of substantive materials, and V. Geetha for correspondence with participants and production of materials. Special recognition must also be given to the Council office in each country which facilitated all the arrangements and ensured a smooth workshop preparation.

Final acknowledgment should be given to all the participants whose commitment to the issues confronting youth made the workshop a significant event for the 4NE region. 


\section{SUMMARY WORKSHOP ON YOUTH ACROSS ASIA}

In Kathmandu, Nepal in September 1997, the Population Council, the FOCUS on Young Adults Program and the Futures Group International, with support from the ANE and Global Bureaus of USAID, organized a workshop with more than 70 ANE policy makers, program managers, youth and the media from eight countries to better understand the implications of population momentum and the challenges facing youth in achieving reproductive health in Asia, and to facilitate the formulation of effective policies and services to address these issues.

The issues facing youth across Asia are as diverse as the cultures they represent. Yet issues of schooling, employment, sexuality and marriage all take on increased significance for young people from 10 to 24 years of age in every country. Few programs, outside of public education systems, exist at a sufficiently large scale to assist youth in making this transition. Gender and equity issues compound many of the problems programs face in addressing youth.

Already accounting for about 25 percent of the region's population, this age group will continue to grow in most countries during the next $\mathbf{3 0}$ years. Due to population momentum, growth will be largest among those countries where fertility has been highest during the past twenty years. In countries like India and Bangladesh, nearly two thirds of population growth during the next century will be due simply to the young age structure. Momentum is attenuated by increasing the age of marriage, delaying the first birth, and spacing subsequent births.

Based on country level analyses, the participants identified three areas needing attention:

$\boldsymbol{o}$ Better data is required for policy development on the needs of youth. Their participation as stakeholders is required for setting priorities.

o Youth issues must be addressed in a broad context. not merely from a reproductive health perspective. Education, employment, empowerment and family formation all are critical issues, requiring broad social awareness of the dimension'; of the problems and debate on the solutions.

$\boldsymbol{o}$ It is important to document and disseminate the experiences of functional information and service program models for youth already operating in the ANE region to encourage replication.

All countries are now developing advocacy strategies for youth, and following up on national plans. Meeting the needs of youth in the long run will: 1) create the conditions for delayed, chosen, and safe sexual relations, marriage and child-bearing. 2) increase educational levels, especially for girls, and increase parental commitment to investments in children, and 3) create the basis for stronger families by promoting a better balance of responsibility between men and women for the social and economic costs of children. 


\section{INTRODUCTION}

The issues facing youth across Asia are as diverse as the cultures they represent. Yet issues of schooling, employment, sexuality and marriage all take on increased significance for young people from 10 to $\mathbf{2 4}$ years of age in every country. Decisions made by youth and their families will dramatically effect their individual welfare, as well as that of their future families and communities. Few programs, outside of public education systems, exist at a sufficiently large scale to assist youth in making this transition.

Decisions to stay in school, opportunities to learn marketable skills, manage resources, the exercise of sexual responsibility, and the process of family formation all impact significantly on personal welfare as well as community development. Gender equality issues compound many of the problems. For example, in much of south Asia, fewer than half of all eligible youth are enrolled in secondary school. Yet for girls, enrollment is often less than half of that for boys (UNICEF, 1997).

This age group, already accounting for about 25 percent of the region's population, will continue to grow in most countries in the region during the next 30 years. Due to population momentum, growth will be largest among those countries where fertility has been highest during the past twenty years. In countries like Bangladesh, India and Egypt, nearly two thirds of population growth during the next century will be due simply to the young age structure. Momentum is attenuated by increasing the age of marriage, delaying the first birth, and spacing subsequent births. Many of these issues in the Asian context are not the decisions of individuals or young couples alone, but of parents, families and communities. They are essentially social issues, requiring social awareness of the dimensions of the problems and debate on the solutions.

\section{OBJECTIVES}

The objectives of the workshop were to better understand the implications of population momentum and the challenges facing youth in achieving reproductive health in Asia, and to facilitate the formulation of effective policies and services to address these issues. Meeting the needs of young women and men from 10 to 24 years of age in the long run will:

o Create the conditions for delayed, chosen, and safe sexual relations, marriage and childbearing.

o Increase educational levels, especially for girls, and increase parental commitment to investments in children, particularly their education.

$\boldsymbol{0}$ Create the basis for stronger families by promoting delayed chosen marriage, and a better balance of responsibility between men and women for the social and economic costs of children.

- $\quad$ Provide the information to young people necessary for them to have voluntary and safe sexual and reproductive lives. 
The workshop was organized by the Population Council, the FOCUS on Young Adults Program and the Policy Project of the Futures Group International. Support for the workshop was provided by USAID, both the Global Bureau, Office of Health. Population and Nutrition, and the Regional Bureau for Asia and the Near East.

The meeting was held over a three day period in Kathmandu. Nepal. The style of the meeting was highly participatory. Formats for sessions included plenary presentations, panel discussions, break out groups, field trips and interactive group discussions (See the appendix.)

\section{PARTICIPANTS AND THEIR EXPECTATIONS}

The planning committee invited six individuals from the five countries in Asia in which there is a USAID Mission - Bangladesh, India, Indonesia, Nepal and the Philippines. Other participants were invited as resource persons from successful or promising programs in Egypt, Pakistan, Thailand, and Vietnam. A total of 67 persons attended the event and additional Nepali guests attended selected sessions. Participants included policy makers. program managers, health and communications specialists, and youth from about eight countries in the region. They included leaders from reproductive health programs for youth in government bodies, non-governmental organizations (NGOs), universities, the media, and international donor organizations. Members of the media attended from Bangladesh, India, Indonesia, Nepal and the Philippines.

In addition to country participants, partners and resource persons cooperated in the discussion. Organizations participating included: USAID. East-West Center, CEDPA, AVSC, PCS, JHPIEGO, the Red Cross, Pathfinder, UNFPA, Department for International Development (DfID/UK), the Ford Foundation, Thai Youth AIDS Prevention, and the "oundation for Women, among others.

Participants' expectations about the workshop were the following:

- $74 \%$ - learn from and about other people who are working on youth issues

o $66 \%$ - learn more about reproductive health policies for youth

o $61 \%$ - learn more about reproductive health programs for yauth

o $61 \%$ - share experiences and information on youth activities

o $57 \%$ - learn about the diverse groups in addressing youth needs

o $49 \%$ - develop follow-on country activities for youth

o $10 \%$ - share in networking

- $6 \%$ - identify opportunities and constraints facing programs

o $6 \%$ - define a research agenda on youth

The interest in networking and using the flexible agenda to share experiences with colleagues from other countries was particularly noteworthy. 


\section{PRESENTATIONS}

The workshop was inaugurated by Dr. Mangal Siddhi Manandhar, Vice-chairman of the National Planning Commission of Nepal. He noted that youth in Nepal, and indeed the entire region, are facing many challenges in continuing their education, competing in the job market, understanding their rights to decide about reproduction, and getting quality health services. How they behave and what opportunities they have today will effect their future families and in turn the country. He also noted that two recent United Nations conferences on population and on women have urged that young people be given better protection from harm and better access to resources, including reproductive health care. The 1994 International Conference on Population and Development recommended that each country enact laws supporting young people and to allocate resources to implement that legislation. Similarly, the International Conference on Women held in 1995 in Beijing reaffirmed the importance of meeting the health needs of women, especially young women.

John W. Townsend of the Population Council and Chris McDermott of the ANE Bureau of USAID reminded the participants that the broad issues surrounding youth are also embedded in the context of population growth and momentum. They pointed out that youth are a large and growing part of the global population - 1.6 billion youth aged 10 to 24 years of age. Of these, 85 percent live in developing countries and they comprise 25 percent of the population of Asia, with enormous consequences for national development. Saroj Pachauri of the Population Council highlighted the issues and challenges facing reproductive health programs for youth across Asia. She concluded that reproductive health programs for youth will face a lonely challenge until the community decides to guide young people about sexuality. No health or education program will ever have the resources to make a great difference to people's lives if it must work against social norms. The goal of any program for youth should help to change this situation, and this requires advocacy.

Presentations in plenary sessions were also made by several invited speakers. Peter Xenos of the East-West Center, Program on Population, discussed the demographic transformations among Asian youth. He highlighted the secular trends in increasing school enrollment, and the gender dimensions evident in the national trends in the percentage of young men and women who are single and out of school. While the proportion of young women who are single and in school is increasing in most countries, most young women in the region still leave school earlier than men and marry earlier, leading to early childbearing and continued population momentum. Kokila Agarwal of the Futures Group International presented the elements of policy advocacy and highlighted the policy issues that impact young adult reproductive health. She concluded that policies support programs, but cannot be considered in isolation of programs. And she emphasized the need to consider policies and practices that go beyond increasing reproductive health service availability, and which look at selfesteem and life options. Md. Alauddin and Ann McCauley of Pathfinder International presented a description of program models for reproductive health services for youth, including young married couples. They concluded that community networks can be effectively used for changing traditions to benefit youth. 


\section{SUPPORT MATERIALS}

In addition to plenary presentations, several types of documents were prepared and distributed to each participant to stimulate discussion. A chart book was prepared which included key elements from the Convention of the Rights of the Child, and the ICPD Plan of Action. It also included ten charts with basic information on youth in eight countries in the region, illustrative quotations from youth and their families on the issues confronting them, and qualitative data on selected reproductive health problems. The chart book was also designed to assist participants in preparing presentation on the status of youth in their own countries.

A second set of materials was compiled as a reader. It contained 12 key articles selected by the FOCUS on Young Adults Program which examined issues of youth sexuality, sex education, adolescent reproductive health and adolescent fertility. The reader was supplemented by a plethora of papers on global issues, e.g., McCauley and Salter. 1995, as well as papers on country specific issues, which were contributed by participants. The most useful of these are cited in the bibliography. In addition, five country studies were com missioned:

- $\quad$ Married Youth: The Bangladesh Case, by Ubaidur Rob and M. Alauddin.

- $\quad$ Adolescent Reproductive and Sexual Health Needs: India, by Sagri Singh

- $\quad$ Needs and Risks Facing the Indonesian Youth Population, by Desti Murdijana

- Schooling, Marriage, Work, and Childbearing among the Youth of Nepal: Emerging Insights and Challenges, by Shyam Thapa, Laxmi Bilas Acharya and Ram H. Aryal

- $\quad$ Promoting the Well-being of Filipino Youth, by Grace Aguiling-Dalisay

Each paper provided an analysis of local policy issues and available data on the needs of youth. Where specific programmatic efforts have been made, e. 5., Bangladesh and Indonesia, a summary of lessons learned were included.

\section{SECTOR ISSUES}

The first group discussion was organized by sector. Each group was asked to identify key issues that should be discussed in plenary. Young people were given the option of joining a sector discussion or the youth group. The key points from these sector discussions are presented below:

\section{Public Sector}

- Information and services for health, including reproductive health, should be made available to married and unmarried youth.

o Formal and informal approaches to family life education should be provided in schools and in other settings for out of school youth.

- There should be an integration of policies invislving health, education and employment which link reproductive health with all athe' development programs. 


\section{Non-Government Organizations (NGOs)}

- NGOs have a comparative advantage in that they can freely interact with the civil society and are not restricted in the formulation of strategies and development of projects. They can employ appropriate techniques to deal positively with sensitive local issues.

- Grouping of youth by age categories may overlook some of the issues that they face. Appropriate elements of information and services should be introduced in a progressive fashion from 10 to 24 years.

$\boldsymbol{o}$ Many social groups influence the attitudes arid behavior of children. To remove social constraints, families, policy makers, community leaders and peers should be involved in designing services. Each should be provided with training and education on youth.

\section{Youth's Themselves}

- Provide information and education on sexuality and reproductive health to youth, their families and the community in which they live.

$\boldsymbol{o}$ Offer programs and provide services that address the perceived needs of youth and go beyond the population education and HIV/AIDS prevention frameworks.

- Provide holistic programs to address youth's development needs, emotional and maturation needs, relationships with family and peers. and youth'. aspirations.

The priorities of the three groups are compatible, but do thev reflect the perspective of each group, as planners, community leaders and youth. The sector assessinents allowed participants to think broadly, beyond their national setting, about the needs and program options for youth in the region.

\section{POLICY ENVIRONMENT}

A supportive policy environment is a major factor in the success of most, but not all, national programs. While the importance of a supportive policy environınent has been recognized, less effort has been devoted to determining what constitutes that environment and how to measure changes or improvements in it over time. The Policy Environment Score (PES) is a tool that is useful for indicating the overall status of the policy environment for various reproductive health components in a particular country. evaluating changes in the policy environnent over time, and identifying those areas most in need of improvement.

The Policy Environment Score (PES) is intended to measure the degree to which the policy environment in a particular country contributes to improvements in the reproductive health status of the population, with a particular foccs on access to high qualiry family planning and reproductive health services. The PES is designed to provide a quick assessincrnt of the policy environment at low cost. It necessarily contains a number of items that depend on the judgment of experts: Political Support. National Policy (or Policy Formulation). Organizational Structure. Legal and Regulatory 
Environment, Program Resources, Program Components, and Evaluation and Research. During the Workshop on Youth Across Asia, the participants from the representative countries filled out the PES questionnaire. The number of respondents per country ranged from three to nine. The results from the survey are outlined below.

\section{Policy Environment Scores: Youth}

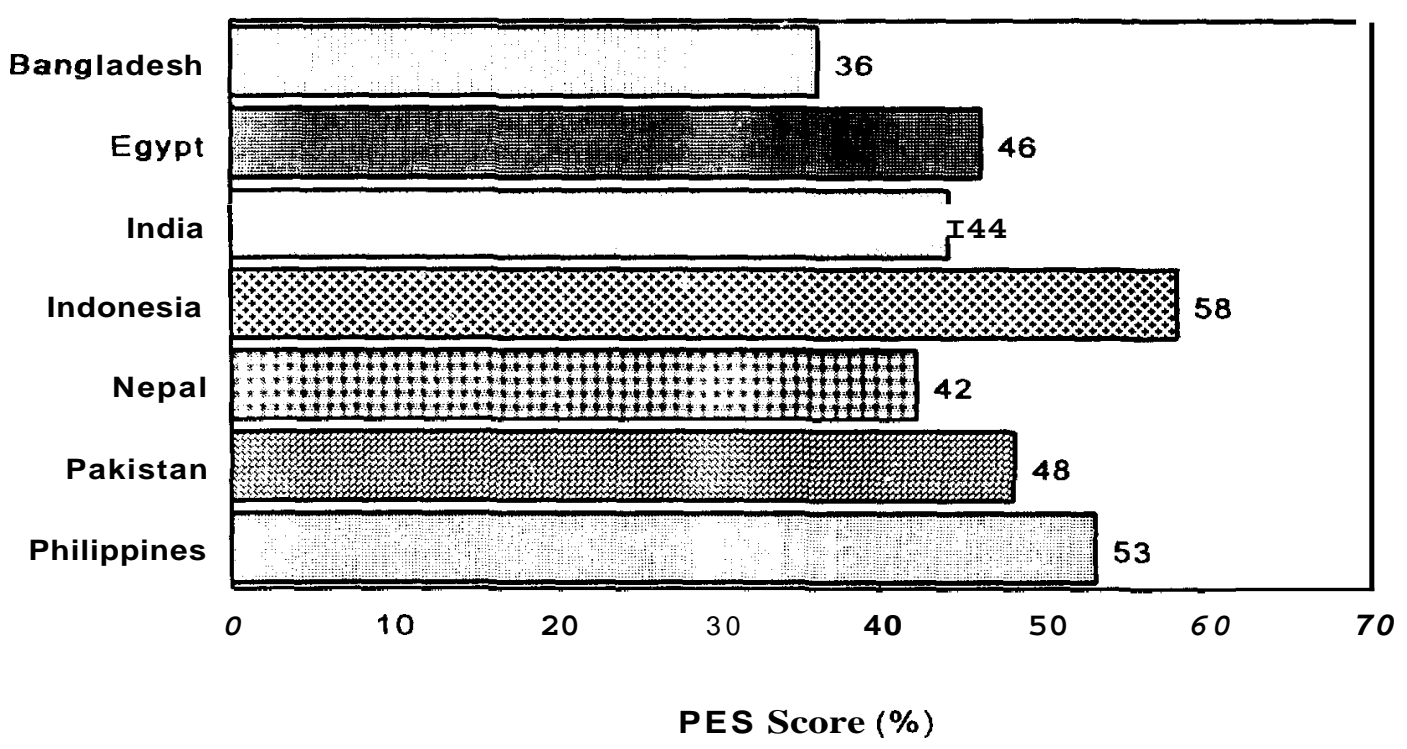

These results reflect a snapshot of the policy environment for youth programs among the countries attending the workshop. A low score indicates a policy environment that may not be supportive toward development of youth programs and policies. Typically the PES is adapted for the country in question and then is filled by 10 or more key influentials and knowledgeable informants. Although at the regional workshop there were a limited number of respondents from each country, they reflected a broad range of expertise and knowledge of the young adult reproductive health situation in their country. This was also reflected in the considerable variability on scores of individual items.

As an evaluation tool, it would be necessary to collect the information from a larger and perhaps more diverse sample from the countries, and follow-up on the initial assessment after a gap of one or two years to estimate the degree of change in the particular policy environment. The analysis can then reflect the comparative status of the policy environment for youth programs and which components of the policy environment changed in the interim. The PES does not lend itself to cross-country comparisons. 


\section{FIELD VISITS}

Six field visits were organized by Save the Children/USA for participants to meet with community leaders and programs in the Kathmandu Valley dealing with youth. Visits included:

o HIV prevention counseling for incarcerated men and their families by the Women's Inspiration Community (WICOM) at Nahkhujail.

$\boldsymbol{o} \quad$ HIV prevention services for injecting drug users supported by Lifesaving and Lifegiving Society (LALS).

$\boldsymbol{o}$ Reproductive health services for young factory workers sponsored by B.P. Memorial Health Foundation, in collaboration with Himalayan Healing Center Clinic.

- A training and support program (PRERANA) for youth living with HIV.

- The Family Planning Association of Nepal (FPAN) offers several services addressing the needs of young women for both skills' development and reproductive health.

$\boldsymbol{o} \quad$ A street theater group (Aaronhan) presented a my thical story of a youth with AIDS.

The visits were instrumental in highlighting the needs of specific groups, e.g., the unmarried, the recently married, working youth, and those with special problems such as HIV infection, or those in jails. It is important to develop programs which reach all segments of youth, not simply those in school, girls alone, or only those who are married.

\section{COUNTRY PLANS}

Each country team met to identify specific policy and programmatic issues to be addressed following the workshop. Many of the delegations addressed program components as well, identifying the need for advocacy, services for youth. and the importance of working with the media and others to stimulate public discussion on the needs of youth. The program models discussed often grew out of current proposals under development, or presentations made and materials distributed at the workshop. The following are some highlights of priority policy issues and the group's interest in following up on the workshop.

\section{Bangladesh}

\section{Policy Objectives: Priorities}

- Create awareness about reproductive health issues and needs of youth among the media, program managers, policy makers, and community and religious leaders.

- Develop country specific youth profiies highlighting elements of youth life.

- Create a national level youth forum representing different sectors. 


\section{Proposed Follow-up \\ a Create a national coordination committee on youth. \\ a Identify the programmatic and research needs. \\ a Organize a national level workshop on youth}

\section{Egypt and Pakistan}

\section{Policy Objectives: Priorities}

a Identify the specific needs and issues confronting subgroups of youth in the country in a participatory fashion.

a Open constructive public debates on the concerns of youth with their own participation.

a Increase the information and knowledge available to all stakeholders leading to policy development and program action.

\section{Proposed Follow-up}

a Encouragejoint learning and better partnerships among NGOs, the private and public sector on youth issues.

a Link the planning of reproductive health services for youth more effectively with other youth services in education. employment, sports. community participation and health.

\section{India}

\section{Policy Objectives: Priorities}

- Increase the availability of accurate information for youth.

a Improve the access of youth to services which address their needs.

a Support emerging service models at the community level as well as media efforts for outreach.

\section{Proposed Follow-up}

a Conduct policy and program oriented research to provide data on what is being done in India for youth as well as to increase policy makers' access to information on youth.

- Build partnerships and alliances with representatives from the media, donors, NGOs, and government agencies involved with youth,

a Conduct regional meetings on youth at diverse levels within India to increase the awareness and better understanding of local needs of ' outh and share lessons learned. 


\section{Indonesia}

\section{Policy Objectives: Priorities}

- Improve reproductive health education and information nationally through the creation of a national strategy.

- $\quad$ Provide education, information and care to young people from the ages of six to 24, in ways that are appropriate to their age and experience.

- Create opportunities for skills development and vocational training in order to prepare youth (age 15-24) for self-reliance, productivity and entrepreneurship.

\section{Proposed Follow-up}

o Establish a network for communication of groups working on youth's reproductive health.

o Report on the results from the workshop to the BKKBN Executive Seminar in October, and to the Ministry of Health Workshop on School Health Programs in November 1997.

- Design and implement a young adult reproductive health survey in 10 districts and urban areas of East Java and Central Java.

- Develop the terms of reference for a youth assessment which would meet the information needs of stakeholders, national organizations and donors.

\section{Nepal}

\section{Policy Objectives: Priorities}

o Increase schooling, especially for girls less than 15 years of age.

- Develop policies focusing on youth employment and the labor force.

- Address sexual and reproductive health counseling anti service needs.

\section{Proposed Follow-up}

o Form a policy development iask force, and develop a national working committee, with government and NGOs, to implement program initiatives.

- Conduct focus group discussions with youth to learn more about their perspectives.

o Organize a round table discussion with NGOs and GON on issues raised by the workshop, and incorporate results of qualitative study of youth. 


\section{Philippines}

Policy Objectives: Priorities

- Inform and provide services to youth, 15-24 years of age.

- $\quad$ Provide formal and non formal family-life oriented education programs.

- Promote an integrated and holistic approach to youth development.

\section{Proposed Follow-up}

- The Commission on Population will provide leadership in development of a plan of action.

- Form a working group with participants from the sovernment and NGOs to follow-up on the plans developed at the workshop.

- Advocacy groups will ensure that the commitments for information and communication for youth are carried out.

As can be noted, the proposed policy objectives and plans for follow-up touch common themes, while at the same time differ dramatically in the degree of specificity and organizational context. Egypt and Pakistan formed ajoint group, not to set a common agenda, but to learn from each other on how to approach youth issues in the health sector A number of delegations had met several times prior to the workshop to review the country paper or work on joint activities already in progress, e.g., India, Bangladesh, Indonesia and the Philippines Wherc this occurred. the group discussions were more focused, or led to a more feasible follow-up proposal. Participants from Thailand and Vietnam as well as donors and partners served as re iou ce persons in several groups.

\section{CONCLUSIONS}

Following three days of discussion. the participants reached five overall conclusions:

- Youth needs should be addressed holistically,

- Planners want and need to know more about youth needs -- and they want to hear from young people themselves about their needs

- Programs should meet a wide variety of youth reeds;

- Policies should support the welfare of young people; and,

- Efforts to address youth issues may require a change in social attitudes toward youth -- an end that may be best achieved through public cebate of the youth issues.

The discussion that led to these conclusions is sumina ized below. 


\section{Youth needs should be addressed holistically}

Participants felt that the positive physical, psychological and behavioural changes that young people go through, including sexual development, need to be included in reproductive health programs for youth. Decision making risks and ways to avoid a range of health and social risks need to be addressed as well. Yet participants noted that the causes and solutions to adolescent reproductive health problems often lay outside the realm of health services. For example, they felt that young people with educational and employment opportunities would be less likely to engage in unsafe sexual behaviours. Therefore, participants wanted programs and policies to address the range of adolescent needs rather than focus narrowly on reproductive health alone.

Policy makers should look at how the following factors effect the health of youth:

- Customs that promote marriage at a young age and the expectation that a young couple will have children soon after marriage;

- Gender assumptions or stereotypes that prevent young people from developing in positive, healthy ways;

o The consequences of cultural conceptions of sexuality;

- The effect of limited education and employment on the willingness of youth to delay having sexual intercourse, or to adopt safe sexual behaviors;

o Economic circumstances or customs that pressure young people into having sexual relationships;

- Situations in which young people have sex against their ou n will; and,

$\boldsymbol{o} \quad$ The ease with which young people can gain access to accuiate information and services to protect their health, including their reproductive health

\section{Planners want and need to know more about youth needs - and they want to hear from young people themselves about their needs}

Participants felt that they should know more about what young people needed. Few countries have accurate data on young people's needs including unplanned pregnancies, sexually transmitted infections, unemployment, lack of access to education, or gender inequality in access to opportunities. Planners wanted more information upon which to base proposed actions. They also felt they needed better research tools to measure the effectiveness of programs for youth.

Participants stated that in working with young people they had learned a great deal about how young people thought and felt. Having young people identify their own needs was strongly supported during the workshop. Participants from the Philippines noted that a local newspaper column in which young people identify their own concerns was both surprising and helpful to those working with youth. Participants familiar with a telephone hotline in India commented that the young callers asked questions that adults rarely considered. They suggested tha! working with young people to identify their needs was an efficient and necessary step to designing programs and policies that really suited young people. 


\section{Programs should meet a wide variety of youth needs}

Because participants felt that the health needs of youth were influenced by many factors, they supported programs that dealt with multiple needs. Several participants, for example, mentioned that programs should address the economic factors that lead to high-risk behavior, as well as provide health information and services.

To deal with diverse youth needs, participants recommended that programs be designed for special groups. Participants from Bangladesh, for example, discussed efforts to reach married young people and those from Thailand described HIV-prevention programs. The workshop concluded that multiple needs might be met through both networks of youth programs or programs that dealt with multiple issues. To improve access to care, participants endorsed both integrating youth health services into broader health programs and developng special efforts to reach youth through their own existing networks.

\section{Policies should support the welfare of young people}

The workshop focused on highlighting a framework to approach youth policy development and on advocacy efforts to achieve those objectives. Participants acknowledged that in many countries there are no formal policies relating to the health and development needs of young people. They proposed that much effort was needed in advocating for development of youth policies that addressed the needs of young adults holistically. The participants felt it was essential to take a broad, multisectoral and participatory approach to youth policy development. To develop effective policies, participants reiterated that young people and youth reprzsentatives should be involved in the policy process.

Representatives at the workshop proposed that is stematic review of youth requirements be undertaken in the area of education, employment preparation for civic involvement, and health issues such as smoking, drinking and reproductive health and sexuality. Based on this broad assessment, policies and goals should be set withiti each sector. The participants recognized that development of policies relating to youth could be \& very sensitive issue within the country and that much greater advocacy effort was required for allc $v$ iating misconceptions surrounding the impact of some program and policy interventions.

\section{Addressing youth issues requires changes in social attitudes toward youth - an end best achieved through public debate on youth needs}

Participants noted that social attitudes. including n ass media coverage, usually portrayed youth and their sexuality as troublesome and demanding Th'y recommended efforts to develop a sympathetic attitude toward youth. Increased public debate on wh issues was seen as key to changing attitudes 
toward youth. Journalists from several countries pointed out that the public knows little about the challenges facing youth, and even less about actions that can be taken to promote the welfare of young people. Participants felt that open discussion of the needs of youth could lead to widespread support for youth-friendly policies in all sectors. They cautioned, however, that debate about youth becomes negative when no one is suggesting and promoting positive ways of addressing youth needs. Therefore, those knowledgeable about youth issues should ensure that journalists, and other leaders are well informed about ways to address youth issues

\section{What suggestions came out of the workshop?}

About 60 percent of the workshop participants, largely those from country delegations, returned the evaluation form. All but two of the respondents found the workshop very useful, as they learned a great deal about adolescent reproductive health issues as well as had the opportunity for networking. While participants found the conference useful, most felt that much more needs to be done to address the needs of youth. Participants called the workshop "a good beginning," and suggested the following activities.

- Listen to young people themselves. For example, qualitative efforts should be made to solicit and document youth perspectives on their own needs. Meetings and workshops should include a presentation by young people discussing their needs and opinions.

- Increase awareness of youth needs. Plan workshops at the regional or national level to continue discussion of the issues. Such workshops promote public debate, disseminate information about useful policies and programs, and increase awareness of the issues.

- Increase skills in addressing youth needs. Plan workshops specializing in one aspect of the issue such as research, policy, sexuality, or programs, and communicate results broadly.

- Promote public debate that leads to policies that support youth. To make sure that such debate is constructive, those familiar with youth issues should develop materials and short educational courses for specific groups such as government officials, NGO's, media, and other groups.

- Develop holistic solutions to youth needs. Develop regional or national networks for those working with youth to increase cooperation and informalion among programs addressing different youth issues. 


\section{WHAT HAS HAPPENED SINCE:THE WORKSHOP: SIX MONTH FOLLOW-UP}

One of the goals of the workshop was to actuallv stimulate changes in the policy and program environment of the region. Follow-up was considered an important feature of this workshop, whose influence was not supposed to end in September 1997. During the past six months, the partners involved in the organization of the workshop completed the following tasks:

The partners organized with the ANE Burcau/USAID a plenary and two breakout sessions at the PHN Regional Workshop in Chiang Mai, Thailand in September 1997, which summarized the issues raised in the Youth Across Asia Workshop, and provided input into potential USAID bilateral strategies at the national level. In contrast to previous years, in part due to the advocacy of the ANE Bureau. USAID Missions are beginning to program support for advocacy. service and researcl activities for youth.

- A summary of the workshop conclusions and recommendations was sent to USAID for the Monthly Administrator's Report. A three-page summary of the discussion and recommendations from the workshop wa: prs pared by FOCUS for broader dissemination.

- $\quad$ The Policy Project of the Futures Group International requested proposals for policy analyses on youth issues globally. The Focus on Young Adults Program has proposed supporting several national workshops during 1998 as a follow-on to the Nepal workshop.

- With the support of materials from the workshop, journalists attending the workshop published five articles raising the issue of youth, and supporting policy dialogue and innovations in services in their country.

The Population Council awarded a contract to the East-West Center, Program on Population, to enable Peter Xenos to compile and analyze data on youth across 17 Asia countries in a format which would facilitate utilization by policy makers and program managers at the country level. A summary of general conclusions is presented below. A full report was submitted to USAID in April.

At the core of the youth transition in Asia is a sequence of demographic changes marked most notably by a pronounced youth bulge. This is a one-time, temporary phenomenon tied to the demographic transition itself and particularly to the timing and tempo of fertility decline. Within 20 years of the onset ot significant, sustained fertility decline, the youth share of the total population (15 to 24 years of age) rises from about 16 percent to somewhere in the range of 20-24 percent. and then back down to the pretransition level some 30 years after the onset of fertility decline

The magnitude of the youth bulge is but a part, sometimes a small part, of the overall youth ,transition faced by Asian societies The social components of the youth transition -- 
especially rising percents of unmarried youth, and rising percents of youth enrolled in schools -- produce dramatic growth rates for specific subgroups of the population. For example, the population of youth who are single and out of school, a well-defined risk group and target audience for programs, grew very rapidly between 1950 and 1990 in many countries of South Asia, but declined in most countries of Southeast and East Asia. The growth of this subgroup of youth is projected to continue in South Asia during from period from 1990 to 2025.

The East-West Center will distribute the full report as a Working Paper, and a condensed version of the main results will be published in the Asia-Pacific Population Research Reports.

$\boldsymbol{o} \quad$ The Population Council will publish a special edition of' Studies in Family Planning, in June 1998 on adolescent reproductive behavior in the developing world. It will include eleven papers fiom the 1997National Academy of Sciences Workshop held in Washington, D.C..

Partners have also continued to monitor and support the work of country delegations. Despite the economic difficulties which have battered the region in the past six months, many workshop participants continue to be active in promoting policy and program change, and in seeking financing for projects on youth issues. Highlights of activities being conducted at the national level are provided below. By no means are these the only activities focused on youth in the region, rather they represent initiatives which either grew out the Nepal workshop, or have involved members of the Youth Across Asia delegations in significant roles. Examples of this work are the following:

\section{Bangladesh}

- Under the auspices of the Director General, Family Planning, workshop participants have met several times to discuss and identify priority research issues related to youth. Concerned Women for Family Planning and Pathfinder International will initiate several OR studies, particularly related to services for newly married youth, with technical assistance fiom the Population Council. Concerned Women for Family Planning and the Population Council will develop an advocacy project with female members of Parliament will meet periodically to discuss issues affecting youth in Bangladesh.

$\boldsymbol{o}$ The working group will prepare a directory of NGOs which are providing services to adolescents, particularly in urban areas. The directory will include contact information as well as a summary of the types of activities supported and specific services provided.

- A workshop will be organized in 1998 by the working group on adolescents in Dhaka, and a chart book providing basic information on youth will be prepared. 
o Dissemination continues on the national survey of youth, which was funded by the USAID Mission and supported by the Council, as a basic resource document for planners on youth. Sajeda Amin of the Population Council continues examining the economic and social issues surrounding the expanding number of youth. particularly young girls, in the garment industry.

\section{Egypt}

- Dr. Moshira El-Sharei, First Secretary Ministry of Health and Population in Egypt, who attended the Nepal workshop, has raised the issue of youth frequently in high level policy discussions. Her regular discussion with the USAID Mission in Cairo is leading to the development of a local plan of action. Youth issues were highlighted in a national meeting in December 1997 on the role of emergency contraception in Egypt.

- The Population Council will sponsor in June 1998 a high level multi sectoral meeting with representative of the public and private sectors to review policies affecting youth in Egypt.

- The Population Council continues to work with the Ministry of Education on attracting and keeping middle school girls in the classroom. Issues of safety, self-esteem and gender are being examined both through classroom observations and in the analysis of curricula and text materials.

\section{India}

- A working group has been formed with NGOs, UNFPA and the Council to assist the government to articulate and publish youth policies in three sectors, i.e., family welfare, HIV/AIDS prevention, and education, youth and sports. The working group meets periodically with relevant policy makers and through analysis contributes to the development of policy. Specifically, the role of the working group is to compile and analyze information to better inform policy and program implementation, build alliances between organizations working with youth, as well as to serve as a conduit for diffusion of information on youth.

- The Council is collaborating with UNFPA arid several NGOs, including MAMTA, on a proposal to document best practices among youth service programs, and identify the most innovative services in 10 states. CEDPA is working with women's health advocates to focus attention on the sexual exploitation and trafficking of girls. both in India and Nepal.

- The Population Council, with the support of the Ford Foundation, will support several indepth studies on adolescent health and sexuality in the state of Gujarat during 1998. 
o UNICEF, UNFPA, WHO and other donors are collaborating on national consultations and needs assessments for youth. They are also considering the potential benefit of a national survey on youth during 1999. The NFHS, which samples married women 15-49 years of age, will be conducted in 1998 with the support of I JSAID.

o ICRW has completed a series of diagnostic studies on youth conducted by leading health and social science centers such as KEM Hospital. Pune, Christian Medical College, Vellore, the Tata Institute of Social Science in Mumbai, and the Foundation for Research in Health Systems in Ahmedabad. A workshop on final report preparation will take place in May, along with planning for follow-up interventions, with the support of the Rockefeller Foundation. They are planning a national dissemination meeting sometime during late 1998.

\section{Indonesia}

o In Indonesia. workshop participants are involved in a national project to prepare parents to discuss reproductive health with their children, funded by the World Bank. With funding from UNFPA, workshop participants from the MOH, BKKBN and others have developed reproductive health briefing materials for parents and older students.

o BKKBN, with the support of the University of Indonesia, East-West Center and UNFPA, is preparing a pilot survey to identify youth needs in rural districts and urban areas of East and Central Java. It will form the basis for a larger needs assessment of young adults within Indonesia's family planning, reproductive health, and HIV/AIDS program.

$\boldsymbol{o}$ The Council is cooperating with the Indonesian Family Planning Association through the Yogjakarta clinic on documenting qualitative perspectives of youth on unwanted pregnancy, and development model service delivery for youth in need of reproductive health care. The clinic is already a model for youth services and was the subject of the country paper for Indonesia.

\section{Nepal}

o The government of Nepal developed in December 1997 its National Reproductive Health Strategy, and significantly it includes adolescent reproductive health as one key element. Though no detailed programming has yet been done, the strategy has one of its specific objectives bringing down the proportion of adolescents 15-19 years of age, who have begun childbearing to 20 percent in 2001 from the current levtl of about 24 percent.

o Also within the government, the Department of Health Services is addressing adolescent groups through the use of mass media, specifically radiu programs which blend music and 
health messages for young audiences. 1t is also conducting operations research with the support of UNFPA to determine the situation of' youth with respect to reproductive health and family planning and to recommend policy and operational guidelines for services.

- Among NGOs, qualitative documentation of youth needs and services continue to be conducted. Most of the NGOs who attended the workshop have increased their activities in both stimulating public discussion about the needs of youth as well as providing services for HIV/AIDS prevention and safe sexual behavior

- Following the Youth Across Asia workshop, USAID/Nepal has decided to support a survey on youth. The survey is likely to use both qualitative and quantitative approaches to collect data on youth topics, include sexuality. '1 he tudy will be conducted through Family Health International and the East-West Center.

\section{Pakistan}

- The Family Planning Association of Pakistan continues to develop its advocacy and service program for youth in Lahore. Materials provided by the Nepal workshop provided ideas for networking and program content. Pathfinder International provides technical assistance on related youth activities.

o Women's rights groups have begun focusing on young women, particularly sexual violence and decision making on the timing and selection of partners for marriage. They have been facilitated access to information and materials from the workshop for reference.

\section{Philippines}

o Following the youth workshop, the government of the Philippines included adolescent health and youth development as one of the action items in the Directional Plan of the national population program. Specifically, the action agenda includes "providing the youth/adolescents information and service.; to help them understand their sexuality and protect from the many risks that threaten the quality of their lives, and also harnessing the adolescents' and youth's potential to develop their capabilities." The USAID Mission uses this Directional Plan 1998-2003 to develop its biiateral program.

- Following the workshop, the participants formed the Philippine Adolescent Core Group under the direction of Mr. Tomas Osias from POPCOM. They meet monthly to further implementation of plans for youth. A series of activities has already been undertaken by this group: an analysis of trends in adolescent fertility/sexuality comparing the two youth surveys, the development of a polics framework for the adolescent health and youth 
development program (AHYDP), development of materials and planning for reproductive health training for parents, the process documentation of successful youth projects and a workshop for the media on youth policy concerns.

\section{Vietnam}

- The Ministry of Health and the Population Council organized a seminar in Hanoi on Youth Reproductive Health in December 1997. The theme grew out of research conducted for the Ministry of Education and Training and UNICEF, which highlighted youth's lack of access to information on HIV/AIDS and sexuality, and their limited opportunities for recreation. Further analysis is continuing to better understand the decision making process, and how practices and contexts can be influenced and strengthened to decrease youth's vulnerability to HIV/AIDS.

- Jointly with the Quang Ninh Red Cross, the Council has introduced a "Soccer and HIV/AIDS" project which teaches out-of-school youth about sexuality and HIV/AIDS through informal fitness, counseling, and health education for youth in Ha Long City. Other organizations like UNFPA and Save the Children/USA have expressed interest in expanding the program to other cities.

It is noteworthy that those countries that had already mobilized to collect data on youth as the basis for advocacy and used country data in their strategies for developing youth policies and programs were the most developed in their follow-up to the Nepal workshop, i.e., Bangladesh, India, Indonesia, and the Philippines. Clearly at this stage of policy development in the region, national data on youth provides a common platform for discussion, and the opportunity for a new awareness of youths' needs.

It is evident from the follow-up information that the workshop on Youth Across Asia provided a key stimulus to national groups seeking to better understand and serve youths' needs. At the same time, while data on population momentum may attract policy makers to the discussion of youth, it is actually focusing on youth needs which will allow programs to better improve reproductive health as well as contribute to future population stabilization. 


\section{REFERENCES}

Adolescent Education with AIDS Awareness Programme in Schools of Jaipur City: A Process Documentation, Concerned Citizens for Community Health and Development, Jaipur, India, February 1997.

Adolescent Reproductive Health, Network, Volume '7, vo.3. Family Health International, Spring 1997.

Agarwal, Kokila, Policy Advocacy, Presentation made in Youth Across Asia Workshop, Kathmandu, Nepal, 23-25 September 1997.

Birdthistle, Isolde, Cheryl Vince-Whitman, Reproductive Health Programs for Young Adults: School-Based Programs, FOCUS on Young Adults. Pathfinder International June 1997.

Bongaarts, John, Population Policy Options in the Developing World, Science, Volume 263, February 1994.

Bongaarts, John, Sajeda Amin, Prospects for Fertility Decline and Implications for Population Growth in South Asia. Paper Prepared for the IUSSP Seminar on Comparative Perspectives on Fertility Transition in South Asia, Islamabad. Pakistan, 17-20 December 1996.

Capoor, Indu, Sonal Mehta, Talking About Love and Sex in Adolescent Health Fairs in India. Reproductive Health Matters, No. 5, May 1995

Chauhan, Seema. Sabrina Evans, Nicole Levesque. Renuka Motihar, Sunil Mehra, A Flower that could have Blossomed: A Country Report on Adols scent Girls in India, CEDPA, 1997.

Cover, Jane, Erin Eckert, Indicators for Reproductive Health Program Evaluation: Final Report of the Subcommittee on Adolescent Reproductive Ilealth Services, Carolina Population Center, December 1995.

Dalisay, Grace Aguiling, Promoting the Well-Being of Jilipino Youth, Country paper prepared for Youth Across Asia Workshop, Kathmandu, Nepal. 23-25 September 1997.

Faiz, Ladly, Hasina Banu, Devi Sharma, Adolescent Family Life Education: Review of Curriculum, Population Research and Development Associates and Population Council, Dhaka, Bangladesh, 1996.

Fraser. Alison M., John E. Brockert, R.H. Ward. Association of Young Maternal Age with Adverse Reproductive Outcomes, Article from The New England Journal of Medicine, Volume 332, Number 17, April 1995. 
Greene, Margaret E., Watering the Neighbow's Garden: Investing in Adolescent Girls in India, Regional Working Paper No. 7, Population Council, New Delhi, 1997

Grunseit, Anne, Susan Kippax, Effects of Sex Education on Young People's Sexual Behaviour, National Centre for HIV Social Research. Global Program on AIDS, WHO, Geneva, no date.

Health Link, NCIH, Conference Issue. May-July 1997.

Haider, Syed Jahangeer, Shamsun Nehar Saleh, Nahid Kamal. Alan Gray, Study of Adolescents: Dynamics of Perception, Attitude, Knowledge and Use of Reproductive Health Care, Population Council, June 1997.

Herrin, Alejandro N.. Marilou P. Costello, Sources of Future Pıpulation Growth and Implications for Public Policy in the Philippines, August 1996

Innovative Approaches in Youth Reproductive Health Programmes, Workshop Report, International Council on Management of Population Programmes, Melaka. Malaysia, 1-4 June 1995.

Jejeebhoy, Shireen J., Adolescent Sexual and Reproductive Behaviour: A Review of the Evidence from India, ICRW Working Paper No. 3, December 1996.

Kirby, Douglas, A Review of Educational Programs Designed to Reduce Sexual Risk-taking Behaviours among School-aged Youths in the United State, August 1995.

Laere, Suzy Van, Vo Van Nhan, Nguyen Thi Van Anh, Ralt Eckhard Ulrich, Reproductive Health Survey 1995: Promotion of Family Health in Five Provinces of Vietnam, National Committee for Population and Family Planning of Vietnam and GTZ, Iunı 1995

Manandhar, Mangal Siddhi, Inaugural Speech, Youth Across Asia Workshop, Kathmandu, Nepal, 23-25 September 1997.

McDermott, Chris, Introductory Comments, Youth Across Asia Workshop, Kathmandu, Nepal, 23 25 September 1997.

McCauley, Ann P. and Cynthia Salter. Meeting the Needs of Young People. Population Reports, Series J., Number 41, October 1995.

Michels, Deb, Shane Brown, Making Sense of Sex: The Diary and the Hotline Project. Reproductive Health Matters, No. 5, May 1995.

Moore, Kirsten, Judith F. Helzner, What's Sex Got To Do With It: Challenges for Incorporating Sexuality into Family Planning Programs, Population Council and IPPF, 1996. 
National Youth Policy 1997 (Draft), Government of India.

Naved, Ruchira T., Sajeda Amin, Margaret Newby, Female Labor Migration and its Implication for Marriage and Childbearing in Bangladesh, Paper Prepared for the PAA Seminar. Washington, D.C., March 1997.

Nayar, Usha A., Young People and Family: Conflicts and Challenges of Growing Up in Mumbai, India. Paper presented in the workshop Youth Across Asia, Kathmandu, Nepal, 23-25 September 1997.

Nhan, Vu Quy, Ngo Dang Minh Hang, Reproductive Behaviour of Unmarried Urban Students of Age 17-24 in Vietnam, National Committee for Population and Family Planning and Centre for Population Studies and Information, Hanoi, 1996.

Pachauri, Saroj, Youth Across Asia: Issues and Challenges. Paper prepared for the Youth Across Asia Workshop, Kathmandu, Nepal, 23-25 September 1997.

Rob, Ubaidur and M. Alauddin, Married Youths: The Bangladesh Case, Country Paper prepared for Youth Across Asia. Kathmandu, Nepal, 23-25 September 1997.

Schneidman, Miriam, Targeting At-Risk Youth: Rationales, Approaches to Service Delivery and Monitoring and Evaluation Issues. World Bank, February 1996.

Senderowitz, Judith, Reproductive Health Outreach Programs for Young Adults. FOCUS on Young Adults, Pathfinder International, May 1997.

Sikes, O.J., Jairo Palacio, Beverley Kerr. Key Non-Controv ersial Concepts of Population Education, International Review of Education, Volume 39, Numbers 1-2, March 1993.

Singh, Sagri, Adolescent Reproductive and Sexual Health Yeeds: India, Country Paper prepared for Youth Across Asia Workshop, Kathmandu, Nepal, 23-25 September 1997.

Syahbuddin, Ieke I., Adolescent Reproductive Health in: Indonesia, Country Paper presented at Youth Across Asia Workshop, Kathmandu, Nepal, 2:-25 September 1997.

Thapa, Shyam, Laxmi Bilas Acharya, Ram H. Aryal, schooling, Marriage, Work and Childbearing among the Youth Population of Nepal: Emerging Insights and Challenges, Country Paper prepared for Youth Across Asia Workshop, Kathmandu, Nepal, 2: -25 September 1997.

Townsend, John W., Esthela Diaz de May, Yolanda Sipulveda, Yolanda Santos de (iar/a L., Sandra Rosenhouse, Sex Education and Family Planning Servic es for Young Adults: Alternative Urban Strategies in Mexico, Article from Studies in Family I'lan ling. Volume 18, Number 2, March-April 1987. 
UNICEF, State of the World's Children. New York. 1997.

Visaria, Leela, Pravin Visaria, Prospective Population Growth and Policy Options for India, 19912 10I. Gujarat Institute of Development Research. Working Paper No. 75. March 1996.

Wilson, David, Albertina Mparadzi. Susu Lavellc. An Ixpcrimental Comparison of Two AIDS Prevention Interventions Among Young Zimbabweans, The Journal of Social Psychology, Vol. 132, Num. 3, pp415-417, June 1992.

Xenos, Peter, Corazon Raymundo, The Social Mapping of Asian Youth at Risk: An Example from the Philippines, Paper Prepared for the Youth Across Asia Workshop, Kathmandu, Nepal, 23-25 September 1997.

Xenos. Peter, The Demographic Transformations of Asian Youth: A Graphical Overview, Paper prepared for Youth Across Asia Workshop, Kathmandu, Nepal. 73-25 September 1997.

Xcnos, Peter and Midea Kabamlan, The Social Deinography of Asian Youth: a Reconstruction over 1950-1990 and Perspectives to 2025. East-West Center, Prourarn on Population, Honolulu, April 1998. 


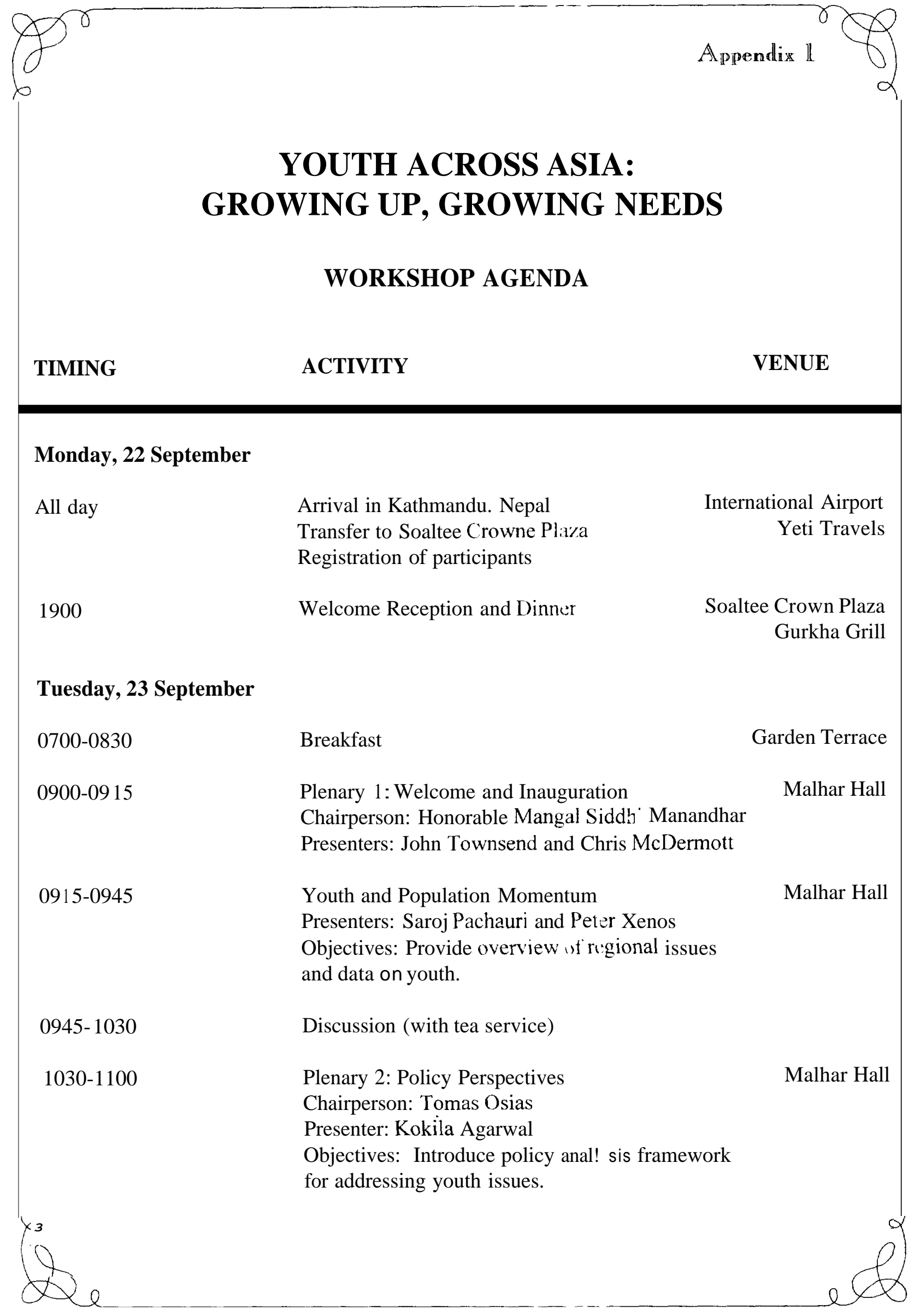


$1100-1115$

Tuesday, 23 September

$1115-1130$

$1130-1300$

$1300-1430$

$1400-1730$

$1430-1500$

$1500-1515$

$1515-1730$

1900

Evening Programme

2000-2 130

2000-2230
Discussion
Malhar Hall

Meeting Rooms

Working Groups by Sectors:

Public, NGO, Media, Youth, and Resource Persons

Objective: Identify policy issues for improving the reproductive health of youth from sector perspective.

Lunch

Himalchuli

Sign-up for Wednesday field visits

Malhar Hall

Plenary 3: Advocacy in Context of Policy

Malhar Hall

Chairperson: Reiny Hariningsih Hardjono

Presenter: Kokila Agarwal

Objective: Provide framework of analysis of country needs.

Orientation for Country Working Groups

Malhar Hall

Country Working Groups: (with tea service)

Meeting Rooms

Bangladesh, India, Indonesia, Nepal,

Pakistan/Egypt, Philippines/Vietnam

Objective: Identify barriers and opportunities

for policy change.

Dinner

Soaltee Crowne Plaza

Sundeck

Participants are invited to visit both sessions

Nepal Country Review

Sunaula A and B

Chairperson: Ananta Raj Pandey

Open Forum and IEC Display

Chairperson: Barbara Ibrahim
Malhar Hall and Lounges 


\section{YOUTH ACROSS ASIA: GROWING UP, GROWING NEEDS}

\section{Wednesday, 24 September}

0700-0830

0830-0930

0930-1015

$1015-1030$

$1030-1300$

$1300-1430$

$1430-1500$

$1500-1530$

$1530-1700$

1930

$2000-2200$
Breakfast

Garden Terrace

Plenary 4: Regional Panel on Youth and Reproductive Health Needs

Chairperson: Moshira El-Shafei

Presenters: Ubaidur Rob, Sagri Singh,

Desti Murdijana, Shyam Thapa, and Grace Dalisay

Discussion (with tea service)

Malhar Hall

Orientation to field trips and departure

Malhar Hall

Visit to Youth Projects in Kathmandu

Six Field Visits

Lunch

Gurkha Grill

Plenary 5: Designing Youth Programmes

Malhar Hall

Chairperson: Meenaksi Sharma

Presenters: M. Alauddin and Aim McCauley

Objectives: Review the range of reproductive

health needs of youth, including information,

skills and services, and models of programme responses.

Discussion and orientation to breakout sessions

Breakout Sessions (with tea service)

Meeting Rooms

Examples of programme responses:

Serving Married Youth - Pathfinder, Bangladesh

Clinic services - FPAI, Indonesia

AIDS prevention - Chiang Mai University, Thailand

Media - Foundation for Adolescent Development, Philippines

Networks - TARSHI, India

Buses depart for Yak and Yeti Hotel

Soaltee Main Entrance

Drama programme and Dinner

Yak and Yeti Hotel

Nachghar Hall 


\section{YOUTH ACROSS ASIA: GROWING UP, GROWING NEEDS}

Thursday, 25 September

0700-0830

Breakfast

Garden Terrace

0900-0930

Plenary 6: Challenges of Social Debate

Soaltee Crowne Plaza

Chairperson: Mohammad Taimur Khan

Sunaula

Presenters: Nerun Yakub, Jasjit Purewal,

Ceres Doyo and John Townsend

Objectives: Highlight social dimensions of

public debate on the needs of youth and responses.

0930-1000

Discussion

Sunaula

$1000-1015$

Orientation to Countr! Working Groups

Sunaula

$1015-1030$

Tea Break and Photograph

Sunaula

$1030-1300$

$1300-1430$

Lunch

Bukhara

$1430-1445$

Evaluation of Workshop

Sunaula

$1445-1530$

Plenary 7: Highlights of the Country Reports

Sunaula

and Plans for Follow-up

Chairperson: Md. Shirajul Islam

Closing Comments: Sharon Epstein

Thursday, 25 September and

Friday, 26 September

Check out and departures

International Airport

Transfer to airport

Yeti Travels 


\section{YOUTH ACROSS ASIA: GROWING UP, GROWING NEEDS \\ 23-25, SEPTEMBER 1997 \\ HOTEL SOALTEE, KATHMANDU \\ LIST OF PARTICIPANTS}

Appendix 2

\section{BANGLADESH}

Md. Shirajul Islam

Director General

Directorate of Family Planning

Population Bhaban,

Azimpur, Dhaka

Bangladesh

Tel: $\quad 88-2-862323$ (Off)

88-2-834213 (Res)

Fax : 88-2-508032

\section{Alauddin}

Country Representative

Pathfinder International

House \# 15, Road \# 13-A

Dhanmondi, Dhaka

Bangladesh

Tel : 88-2-810727-9/ 9110719 (Off) 88-2-883592 (Res)

Fax : 88-2-813048

Email: malauddin@pathfind.org

\section{Ladly Khodezaful Faiz}

Chief'Executive

Population Research \& Development

Associates

F-15, Road 4, Banani

Dhaka

Bangladesh

Tel : 88-2-873119(Off) 88-2-884765 (Res)

Fax: $\quad 88-2-873119$
Nerun N. Yakub

Senior A: ristant Editor

The Bangladesh Observer

67/C Road 9iA

Dhanmandi

Dhaka 1209

Bangladesh

Tel : 8X-2-9555105 (Off) $88-2-9111766$ (Res)

Fax : 88-2-813661

\section{Ubaidur Rob}

Programme Associate

Population Council

P.O.Bux 1016

Gulshan, Dhaka

Bangladesh

Tel: $\quad 88-2-881227 / 8866577$ (Off) 88-2-887589 (Res)

Fax : 88-2-883127/8883132

Email PC DHAKA@popcouncil.org
Ahu Y usuf Choudhury
Director. PIACT
1/9 Iqhal Road, Mohammadpur
Dhaka Bangladesh
Tel : 88 2-812078/818044 (Off) 88 2-812875 (Res)
Fax : 88 2-832975
Email pia $:$ tb@drik.bdg.toolnet.org

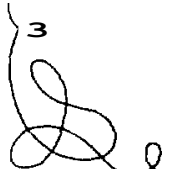




\section{YOUTH ACROSS ASIA: GROWING IJP,GROWING NEEDS}

\section{Shahadat Hossain}

Joint Director/Project Director

Bangladesh Bureau of Statistics

12 Gaznabi Road

College Gate

Mohammadpur

Dhaka-1207

Bangladesh

Tel : 88-2-329998/9110682(Off)

88-2-404722 (Res)

\section{EGYPT}

Barbara Ibrahim

Regional Director for West Asia \& North Africa

Population Council

6A Bahieddine Barakat Street (Giza Street)

Giza, P.O. Box 115

Dokki 12211

Cairo, Egypt

Tel : 20-2-5738277/5725910/5719252 (Off)

$$
\text { 20-2-3505547 (Res) }
$$

Fax : 20-2-570-1804

Email: PCCAIRO@popcouncil.org

\section{Moshira Mohamed El-Shafei}

First Secretary

Ministry of Health \& Population

No.5, Magless Al-Shaab St. ,Mohd.

Cairo, Egypt

Tel: $\quad 20-2-3558097$ (Off)

$$
\text { 20-2-4178441 (Res) }
$$

Fax: 20-2-3558097/3558092

Email:mheapop@idsc 1.gov.eg

\section{INDIA}

\author{
Radhika Chandiramani \\ Director \\ 'TARSHI \\ 2nd Floor, 49, Golf Links \\ Yew Delhi 110003 \\ Tel . 91-11-6481528/4622221 (Off) \\ 91-11-6484036 (Res) \\ Fax: 91-11-4644007 \\ Email: radhi@unv.ernet.in
}

\section{K.M. Sathyanarayana}

Senior Research Associate

The POLICY Project, TFGI

4/2 Shanti Niketan

New Delhi 110021

Tel: 91-11-6886813/4672841(Off)

Fax : 91-11-6885850

Email: kms@policy.globemail.com

\section{Anita Anand}

Director

Women's Feature Service

1, Vizamuddin East

New Delhi-110013

Tel : 91-11-4644606(Off)

Fax : 91-11-4611138

Email:wfs@unv.ernet.in

Lalita Panicker

Senior Assistant Editor

The Times of India

Bahadur Shah Zafar Marg

New Delhi

Tel: 91-11-3717159(Off)

91-11-6228054/6232056 (Res)

Fax: 91-11-3715832

Email: lollyp@ rocketmail.com 


\section{YOUTH ACROSS ASIA: GROWING UP, GROWING NEEDS}

\section{Saroj Pachauri}

Regional Director

Population Council

Zone 5A, Ground Floor, India Habitat Centre

Lodi Road, New Delhi 110003

Tel : 91-11-4642901/4642902 (Off)

$$
\text { 91-11-4641160(Res) }
$$

Fax : 91-11-4642903

Email: pcindiareg@popcounciI.org

\section{Jasjit Purewal}

\section{Convenor}

\section{SAKSHI}

B-67 South Extension Part I

New Delhi - 110049

Tel: $\quad 91-11-4623295 / 6179485$ (Off)

Fax: 91-11-4643946

\section{Vinita Nathani}

Executive Director

PRERANA (Associate CEDPA)

J-332, DDA SFS Flats, Sarita Vihar

New Delhi - 110044

Tel: 91-11-6948876(Off) 91-11-6174388 (Res)

Fax: $\quad$ 91-1 1-6941902

\section{Usha S. Nayar}

Professor \& Chief

Tata Institute of Social Sciences

Unit for Child and Youth Research

Sion-Trombay Road, Deonar

Mumbai - 400088

Tel: $\quad 91-22-5563290-96($ Off)

$$
\text { 91-22-5568837 (Res) }
$$

Fax: 91-22-5562912

E-mail:tash@bom2.vsnl.net.in

\section{Meenakshi Sharma}

Deputy Secretary

Department of Youth Affairs and Sports

Ministry of Human Resource Development Room No.5 17-C, Shastri Bhavan
New Delhi- 110001

Tel: $\quad 91-11-3384408$ (Off)

91-11-7556456(Res)

Fax : 91.11-3387418

\section{INDONESIA}

\section{Desti Murdijana}

\section{Program Manager}

Indonesia Planned Parenthood Association

Yogyakarta Chapter, J1.Tentara Rakyat

Mataram

Gang Kapas Badran - Yogyakarta 55231

Indonesia

Tel : 62-274-513595/586767 (Off)

$$
\text { 62-274-516173 (Res) }
$$

Fax : 62-274-513566

E-mail:Lentera@ins.healthnet.org

Rieny Hariningsih Hardjono

Head of Formulation of Policy \& Evaluation Bureau of Non-Physical Resilience(BINOF) BKKBN

Jl. Permata No. 1 Halim Perdana Kusuma Jakarta 13630, Indonesia

Tel : 62-21-8009125/8009029 Ext. 471475 (Off)

$$
62-21-8583027 / 8623256 \text { (Res) }
$$

Fax: 62-21-8008547

\section{Ridwan Arshad}

Program Officer

Directorate of Youth Affairs

Ministry of Education \& Culture

Jl. Kebon Sirih Barat 1/10

Jakarta Pusat 10340

Indonesia

Tel : 62-21-5725504 (Off)

$$
\text { 62-21-3122526(Res) }
$$

Fax : 62-21-5725041 


\section{YOUTH ACROSS ASIA: GROWING UP, GROWING NEEDS}

Maria Rosita Pr.

Media Consultant

Independent Integrated Media

Communication

Jl. Terusan Hang Lakir IV/40,

Jakarta 12120 , Indonesia

Tel : $62-021-7206221 / 7216090 / 7221025$

Fax : 62-021-7221025

\section{Ieke Irdjiati Syahbuddin}

Head of Sub-Directorate of School-age

Children \& Adolescent Health

Ministry of Health, R.I.

Jl.HR. Rasuma Said Blok X.5 Kav. 4-9

Jakarta, Indonesia

Tel : 62-21-522-1227 (Off)

$$
\text { 62-21-754-3749 (Res) }
$$

Fax : 62-21-520-3884

E-mail: (via Population Council, Jakarta)

\section{NEPAL}

\section{Ananta Raj Pandey}

Joint Secretary

Ministry of Population and Environment

Singhadurbar Secretariate

Kathmandu, Nepal

Tel: $\quad 977-1-245363-65$ (Off)

977-1-371240 (Res)

Fax: $977-1-242138$

\section{Shyam Thapa}

Technical Advisor

Family Health International

Ministry of Health and Population Division

Minstry of Population and Environment

Fifth Lane, Kumaripati, Lalitpur

Kathmandu, Nepal

Tel: $\quad 977-1-2422731245369$ (Off)

977-1-537798 (Res)

Fax: 977-1-537687

E-mail: sthapa@fhi.wlink.com.np

\section{Dhana Malla}

Deputy Project Coordinator of AIDS Program

Save the Children US

P.O. Box 2218

Maharajgunj

Kathmandu, Nepal

Tel: $\quad$ 977-1-412598/412447 (Off)

Fax: 977-1-410375

E-mail:scus@scus.mos.no

Meera Arjyal

Member-Secretary

Ago-Forestry, Basic Health \& Co-operative $\mathrm{ABC} / \mathrm{N}$

GPO Box 5135

Koteshwor

Kathmandu, Nepal

Tel: $\quad 977-1-483346$ (Off) 977-1-521089 (Res)

Fax: 977-1-227372

\section{Harihar Birahi}

President

Nepal Journalist Association

Ramshah Path

P O.Box 5254

Kathmandu, Nepal

Tel: $\quad$ 977-1-419696 (Off)

977-1-471961 (Res)

Fax: 977-1-416033

\section{Prabhat Rana}

Director, Programme Support Services

Division

Family Planning Association of Nepal

P.O. Box 486 Kathmandu

Pulchowk, Harihar Bhawan

I alitpur, Nepal

Tel: $\quad 977-1-524440$ (Off)

977-1-215024 (Res)

H'ax: 977-1-524211

i-mail:drs@no5.com.np 


\section{YOUTH ACROSS ASIA: GROWING UP, GROWING NEEDS}

Dev Ratna Dhakhwa

Secretary-General

Nepal Red Cross

Post Box. 217

Red Cross Marg

Kalimati

Kathmandu, Nepal

Tel: $\quad$ 977-1-270761 (On)

977-1-278738 (Res)

Fax: 977-1-271915

E-mail:nrcs@kalimati.mos.com.np

Mangal Siddhi Manandhar

Vice-chairman

National Planning Commission

Singh Durbar, Kathmandu, Nepal

Tel: $\quad$ 977-1-229070(Off)

977-1-225391 (Res)

Fax: 977-1-226500

Bal Gopal Baidya

President

New Era

Nepal

Tel: $\quad 977-1-413603 / 423176$ (Off)

Fax: 977-1-419562

\section{PAKISTAN}

\section{Mohammad Taimur Khan}

Assistant Director (PP)

Ministry of Women Development, Social

Welfare and Special Education

State Life Building No.5, Blue Area

Islamabad, Pakistan

Tel : 92-51-9206328(Off)

92-51-9205862 (Res)

Fax : 92-51-9203132

\author{
Ali Raza Khan \\ Assistant Director \\ Youth Women and Environment \\ Family Planning Asociation of Pakistan \\ (FPAP) \\ 3-A, Temple Road, Lahore \\ Pakistan \\ Tel : 92-42-6314621-5/6361587-8 (Off) \\ $92-42-417725$ (Res) \\ Fax : 92-42-6368692 \\ E-mail: fpapak@brain.net.pk

\section{Anusheh Hussain \\ Director \\ Sahil} \\ House 8, Street 30, Sector F-8/1 \\ Islamabad, Pakistan \\ Tel: $\quad$ 92-51-254678/260636(Off) \\ 92-51-280987 (Res) \\ E-mail:ahussain@isb.comsats.net.pk

\section{Shahina Malik \\ National Project Officer} \\ Pathfinder, International \\ 5th Floor, Saudi Pak Tower \\ 61-A, Jinnah Avenue, Islamabad \\ Pakistan \\ Tel: $\quad 92-51-201861$ (Off) \\ 92-51-823720(Res) \\ Fax: 92-51-201691
}




\section{YOUTH ACROSS ASIA: GROWING UP, GROWING NEEDS}

\section{PHILIPPINES}

\section{Corazon Raymundo \\ Vice Chancellor \\ University of the Philippines Diliman \\ Office of the Vice Chancellor for Academic \\ Affairs \\ Queen Street \\ Philippines \\ Tel : 63-2-9282889 (Off) 63-2-6413918 (Res) \\ Fax : 63-2-9282863 \\ E-mail:craymund@psdn.org .ph \\ Tomas M. Osias \\ Acting Executive Director \\ Commission on Population (POPCOM) \\ Welfareville Compound \\ Mandaluyong, Metro Manila, Philippines \\ Tel: $\quad 63-2-5316956 / 5316805 / 5316680$ (On)

$$
\text { 63-2-8016871(Res) }
$$

Fax : 63-2-5316907

E-mail: popcom@misa.irf.ph.net

\section{Carolina S. Guerrero}

Executive Officer

Population Education Program

Department of Education, Culture \& Sports

Bonifacio Building

UL Complex, Meralco Avenue

Dasiq City, Philippines

Tel : 63-2-6372745 (Off)

$$
\text { 63-2-6429479 (Res) }
$$

Fax : 63-2-6374766

E-mail:Popedin@webquest.com

Ma. Ceres Doyo

Journalist

Philippine Daily Inquirer

Chino Roces Ave., Makati City,
Metro Manila, Philippines

Tel : 63-2-8978808 (Off) 63-2-6314942 (Res)

Fax : 63-2-8974793/94 (Off)

E-mail:cerespd@aspanet.com

Grace Aguiling-Dalisay

Department of Psychology, UP Diliman

9A Ramax EH, Mapayapa Village 3

Capitol Site, QC

Philippines

Tel : 63-2-9247722 (Off) 63-2-93 16143 (Res)

Fax : 63-2-9205403

E-mail: grace2d@cssp.upd.edu.ph

Helen O.Orande

Project Director

Foundation for Adolescent Development (FAD), Inc.

1140 R. Hidalgo St.,

Quiapo, 1001

Manila

Philippines

Tel : 63-2-7341788 (Off. \& Res)

Fax : 63-2-7348914

E-mail: proc-lea@phil.,gn.apc.org

\section{Ma. Lucelle L. Alamban}

Foundation for Adolescent Development (FAD), Inc.

1140 R. Hidalgo St.,

Quiapo, 1001

Manila, Philippines

Tel : $\mathbf{6 3 - 2 - 7 3 4 1 7 8 8}$ (Off \& Res)

Fax : 63-2-7348914 


\section{YOUTH ACROSS ASIA: GROWING UP, GROWING NEEDS}

\section{VIETNAM}

Tran Le Tra

Program Officer of international Youth Cooperation

Development Centre (CYDECO)

Vietnam Youth Federation (VYF)

64 Ba Trieu Street

Hanoi, Vietnam

Tel: $\quad 84-4-8255709 / 9430358(O n)$

Fax: $84-4-9430358$

\section{USAID}

\section{Chris McDermott}

USAID, Asia and Near East Bureau 1300 Pennsylvania Ave.

Ronald Reagan Building

Washington, D.C. 20523

Tel : $\quad 1-202-712-1647$ (Off)

$$
\text { 1-703-533-6593(Res) }
$$

Fax : 1-202-647-3517

E-mail: cmcdermott@usaid.gov

\section{Zynia L. Rionda}

USAID, Asia and Near East Bureau

1300 Pennsylvania Ave.

Ronald Reagan Building

Washington, D.C. 20523

Tel : 1-202-647-4502 (Off)

$$
\text { 1-703-323-9217 (Res) }
$$

Fax : 1-202-647-3517

E-mail: zrionda@usaid.gov

\section{Leslie B. Curtin}

Supervisory Health \& Population Officer

USAID/Indonesia

Box 4, Unit 8135
APO AP 96520

Tel : 62-21-344-2211 (On)

62-21-799-4800(Res)

Fax : 62-21-380-6694

E-mail: Icurtin@usaid.gov

Matt Friedman

Health and Population Officer

USAID

Rabi Bhawan

P.O. Box 5653

Kathmandu, Nepal

Tel: $\quad 977-1-272424 / 271325$ (Off)

Fax: 977-1-272357

Email: mfiiedman@usaid.gov

\section{DONORS AND RESOURCE PERSONS}

Nancy Russell

Resident Advisor

CEDPANNepal Field Office

C/o 1717 Massachusettes Av NW

WA DC 20036

Tel : $977-1-413069$ (Off) 977-1-418910(Res)

Fax : 977-1-421696

E-mail: cedpa@npl.healthnet.org

Seema Chauhan

Director, Better Life Options (Youth)

Program

CEDPA

1717 Massachusetts Ave., NW

Suite 200, Washington, DC 20036

Tel : 1-202-667-1142(On)

Fax: 1-202-332-4496

E-mail:seema@cedpa.org 


\section{YOUTH ACROSS ASIA: GROWING UP, GROWING NEEDS}

\section{Karuna Onta}

Sr. Program Officer

JHU/PCS Nepal Field Office

P O Box 8048

Kalikasthan

Kathmandu, Nepal

Tel: $\quad 977-1-414652$ (Off) 977-1-416182 (Res)

E-mail:jhupcs@nsm.mos.com.np

Geetanjali Misra

Program Officer, Reproductive Health

The Ford Foundation

55 Lodi Estate

New Delhi 110003

Tel : 91-11-4619441(Off) 91-11-4603051 (Res)

Fax : 91-11-4627147

E-mail: G.misra@fordfound.org

Preeti Kudesia

Project Officerfor West Bengal Reproductive \& Child Health

Department for International Development

Division of Health \& Population

British High Commission

50-M Shantipath, Gate No.3

Niti Marg, Chanakyapuri

New Delhi 110021

Tel : 91-11-6871657(Off)

91-11-7010815 (Res)

Fax : 91-11-6871660

E-mail:p.kudesia@dfid.gtnet.gov.uk

Manisha Mehta

Program Associate

AVSC Intl., 79 Madison Ave., NY

New York 10016

Tel: $\quad$ 212-561-8010 (O)212-663-5013 (Res)

Fax : 212-779-9439

E-mail:mmehta@avsc.org
Malicca Ratne - Castelli

Adviser, RH Information and Counselling

UNFPA CST for Central and South Asia

P.O.Box 5940, Kathmandu

Nepal

Tel : 977-1-523880(Off)

977-1-525576 (Res)

Fax : 977-1-527257

E-mail:cstunfpa@mos.com.np

\section{Amporn Boontan}

Thai Youth AIDS Prevention Project (TYAP)

77/68 Soi 3 Khumcornphing Village Tambon

Suthep

Amphur Muang, Chiang Mai 50200

Thailand

Tel: $\quad 66-53-274157 / 808493$ (Off)

$66-53-881165$ (Res)

Fax : 66-53-808493

E-mail:tyap@loxinfo.co.th

Usa Lerdsrisuntad

Foundation for Women

P.). Box 47

Bangkoknoi Post Office

Bangkok 10700

Tel : 66-2-435-1246 (Off)

66-2-433-5149(Res)

Fax : 66-2-434-6774

E-mail: ffw@mozart.inet.co.th

\section{Jane Wilson}

AVSC International

P.O. Box. 12792

Kathmandu, Nepal

Tel: $\quad 977-1-521377 / 528509$ (Off)

Fax: 977-1-523075

Email: jwilson@avsc.org.np 


\section{YOUTH ACROSS ASIA: GROWING UP, GROWING NEEDS}

\section{PARTNERS AND WORKSHOP SUPPORT}

John W. Townsend

Senior Associate

Population Council

Ground Floor, Zone 5A

India Habitat Centre

Lodi Road

New Delhi 110003

Tel : 91-11-4642901/2902/4008/4009 (Off) 91-11-6888531 (Res)

Fax : 91-11-4642903

E-mail: jtownsend@,pcindia.org

Ann P. McCauley

Communication Advisor

Focus on Young Adults Program 1201 Connecticut Ave. Suite 501

Washington, D.C. 20036

USA

Tel : 1-202-835-0818(Off) $1-410-997-5125$ (Res)

Fax : 1-202-835-0282

E-mail:amccauley(L\&athfind.org

\section{Kokila Agarwal}

Senior Associate

The Futures Group lnternational 1050, 17th Street NW STE\#1000

Washington D.C. 20036, USA

Tel: 1-202-7759680(Off)

$$
1-410-9977175 \text { (Res) }
$$

Fax: $\quad 1-202-7759698$

Email:k.agarwal@tfgi.com

\section{Sharon Epstein}

Project Director

Focus on Young Adults Program 1201, Connecticut Ave., N W

Washington, DC 20036
Tel : 1-202-835-0818 Ext.232 (Off)

$$
1-703-528-2838 \text { (Res) }
$$

Fax : 1-202-835-0282

E-mail sepstein@pathfind.org

\section{Sagri Singh}

Project Director, Adolescent GirlsProgram

Population Council

Ground Floor, Zone 5A

India Habitat Centre

Lodi Road

New Delhi 110003

Tel : 9I-1 I-464290 1/4642902 (Off)

$91-11-4601457 / 4628172$ (Res)

Fax : 01-I 1-4642903

E-mail Sagri@pcindia.org

\section{Peter Xenos}

Senior Fellow, Program on Population

East-West Population Center

177 East W est Road

Honolulu, 1lawaii 96848-1600, USA

Tel : 1-808-944-7410(Off)

- $8118-923-3659$ (Res)

Fax : $1-8(18-944-7490$

E-mail: xenosp@hawaii.edu

Jayanti Tuladhar

Program Associate

Population Zouncil

53, Lodı Estate

Neu Dethi $1 \mathrm{I} 0003$

Tel ' $1-11-4610913 / 4610914$ (Off)

1-1 1-6116628 (Res)

Fax: ',1-11-4610912

Email: Itulidhar@pcindia.org 


\title{
YOUTH ACROSS ASIA: GROWING UP, GROWING NEEDS
}

\author{
Sanjeev Kumar \\ Communications Officer \\ Population Council \\ 53, Lodi Estate \\ New Delhi 110003 \\ Tel: $91-11-4610913 / 4610914$ (Off) \\ Fax: 91-11-4610912 \\ Email: skumar@pcindia.org, \\ pcnewdelhie, popcouncil.org
}

\section{Anjali Nayyar}

Communications Officer

The Population Council

Ground Floor, Zone 5A

India Habitat Centre

Lodi Road

New Delhi 110003

Tel : 91-11-4642901/4642902 (Off)

Fax : 91-11-4642903

Email:pcindiareg@popcouncil.org

\section{Anil Paul}

Manager, Administration

The Population Council

Ground Floor, Zone 5A

India Habitat Centre

Lodi Road

New Delhi 110003

Tel : 91-11-4642901/4642902 (Off) 91-1 1-8527679/8527664 (Res)

Fax : 91-11-4642903

Email: pcindiareg@popcouncil.org 